University for Business and Technology in Kosovo

UBT Knowledge Center

UBT International Conference

2017 UBT International Conference

Oct 28th, 4:30 PM - 6:00 PM

\title{
Raw material of plant origin:cultivation tomato vegetable plant (Solanum lycopersicum) in Kosovo
}

\author{
Nexhat Balaj \\ University for Business and Technology, nexhat.balaj@ubt-uni.net \\ Emine Daci Zejnullahi \\ University for Business and Technology \\ Llazar Haxhinasto \\ Agricultural University of Tirana
}

Follow this and additional works at: https://knowledgecenter.ubt-uni.net/conference

Part of the Food Science Commons

\section{Recommended Citation \\ Balaj, Nexhat; Zejnullahi, Emine Daci; and Haxhinasto, Llazar, "Raw material of plant origin:cultivation tomato vegetable plant (Solanum lycopersicum) in Kosovo" (2017). UBT International Conference. 166. https://knowledgecenter.ubt-uni.net/conference/2017/all-events/166}

This Event is brought to you for free and open access by the Publication and Journals at UBT Knowledge Center. It has been accepted for inclusion in UBT International Conference by an authorized administrator of UBT Knowledge Center. For more information, please contact knowledge.center@ubt-uni.net. 


\title{
Raw material of plant origin: cultivation tomato vegetable plant (Solanum lycopersicum $L$.) in Kosovo
}

\author{
Nexhat Balaj ${ }^{1}$, Emine Daci ${ }^{1}$, Llazar Haxhinasto ${ }^{2}$ \\ ${ }^{1}$ UBT - Higher Education Institution, Lagjja Kalabria p.n., \\ Prishtinë, Kosovë \\ ${ }^{2}$ Agricultural University of Tirana, Faculty of Agriculture, Albania \\ nexhat.balaj@ubt-uni.net
}

\begin{abstract}
Tomato (Solanum lycopersicum L.) is one of the most widely cultivated crops in the world. Tomatoes contribute to a healthy, well-balanced diet. They are rich in minerals, vitamins, essential amino acids, sugars and dietary fibres. Tomato fruits are consumed fresh in salads or cooked in sauces, soup and meat or fish dishes. Tomato is one of the most important and most spread vegetable plants in Kosovo, which has been planted in about 2000 hectares, annually. During our study we used three three hybrids of tomatoes (Better boy,Juliet Amati,) in a commercial farm around the region Prizren, Kosovo, during the vegetation 2015-2016.

During the vegetation period in the periodical way, the following have been measured: biometrical indicators of vegetative masses, biometric indicators of the fruit, dynamic and a total production according to the hybrids. The scheme during the process of the experiment was "randomized block" with four replications. A factorial ANOVA was used to test for significant differences between the treatments combinations.
\end{abstract}

Key words: vegetable, tomato, cultivation, processed raw material

\section{INTRODUCTION}

Tomato (Solanum lycopersicum L.) is one of the most important vegetable plants in the world. It originated in western South America, and domestication is thought to have occurred in Central America. Because of its importance as food, tomato has been bred to improve productivity, fruit quality, and resistance to biotic and abiotic stresses. The cultivated tomato, Solanum lycopersicum L., belongs to the diverse family Solanaceae, which includes more than 3000 species, occupying a wide variety of habitats (Knapp 2002). The Solanaceae contain many species of economic use, such as food (tomatoes, potatoes, peppers and eggplants), medicines (deadly nightshade, henbane, datura).

At present, this plant is common around the world, and has become an economically important crop. Furthermore, this plant is a model species for introducing agronomically important genes into dicotyledonous crop plants (Paduchuri et al. 2010).

The tomato is considered a protective food because of its particular nutritive value, as it provides important nutrients such as lycopene, beta-carotene, flavonoids, vitamin $\mathrm{C}$ and hydroxycinnamic acid derivatives. Furthermore, this crop has achieved tremendous popularity especially in recent years with the discovery of lycopene's anti-oxidative activities and anti-cancer functions (Wu et al. 2011; Raiola et al. 2014). 
Total Kosovar imports of processed fruit \& vegetable products in 2013 amounted to approximately $€ 8.1$ million (8.7 thousand tonnes), having increased at an annual average rate of $2 \%$ since 2009 and experiencing a dip in 2010 and 2011.

The main product groups imported into Kosovo in 2013 were fruit juices, accounting for a share of $22 \%$ of total imports of processed fruits \& vegetables. Product groups jams, jellies, purées and pastes, canned vegetables and tomato ketchup and other tomato sauces closely followed, each accounting for $15 \%$ of total imports. Total Kosovar exports of processed fruit \& vegetable products in 2013 amounted to approximately $€ 631$ thousand (663 tonnes). Considering the product selection described above, the main product groups exported from Kosovo in 2013 were pickled vegetables, ajvar and canned vegetables. Pickled products had a major share of $65 \%$ in total Kosovar exports, whereas ajvar reached a share of $17 \%$ in 2013.

Tomatoes are classified as determinate or indeterminate. Determinate, or bush, types bear a full crop all at once and top off at a specific height; they are often good choices for container growing. Determinate types are preferred by commercial growers who wish to harvest a whole field at one time, or home growers interested in canning. Indeterminate varieties develop into vines that never top off and continue producing until killed by frost.

Numerous varieties of tomato are widely grown in temperate climates across the world, with greenhouses allowing its production throughout the year and in cooler areas. The plants typically grow to $1-3$ meters (3-10 ft) in height and have a weak stem that often sprawls over the ground and vines over other plants.

\section{MATERIAL AND METHODS}

During our study we used three hybrids of tomatoes (Better boy,Juliet Amati,) in a commercial farm around the region Prizren, Kosovo, during the vegetation 2015-2016. During the vegetation period in the periodical way, the following have been measured:biometrical indicators of vegetative masses, biometric indicators of the fruit, dynamic and a total production according to the hybrids. The scheme during the process of the experiment was "randomized block" with four replications. The size of each repetition was $25 \mathrm{~m} 2$. During the experiment is installed drip-drip irrigation system. A factorial ANOVA was used to test for significant differences between the treatments combinations.

Juliet-Referred to as a mini roma because of its shape, Juliets are sweet, crack-resistant tomatoes. Long vines continue setting fruit all summer long and can withstand hot temps.Keep in mind that if you grow hybrids, you'll have to buy new seeds each year. Seeds from a hybrid tomato are not as strong as their parents. Amati" F1 Hybrid- An early indeterminate hybrid suitable for greenhouse and outdoor growing. Fruits are medium large, of average weight $180-220 \mathrm{~g}$, round shape, red color and pleasant taste. The plant has open habitus allowing prolonged harvesting.Better Boy-A Guinness Book of World Records champion, yielding nearly 350 pounds of tomatoes from a single plant over one season, Better Boy really is better! This diseaseresistant, flavorful and easy-to-grow tomato is a classic with the perfect balance of acid and sugar. 


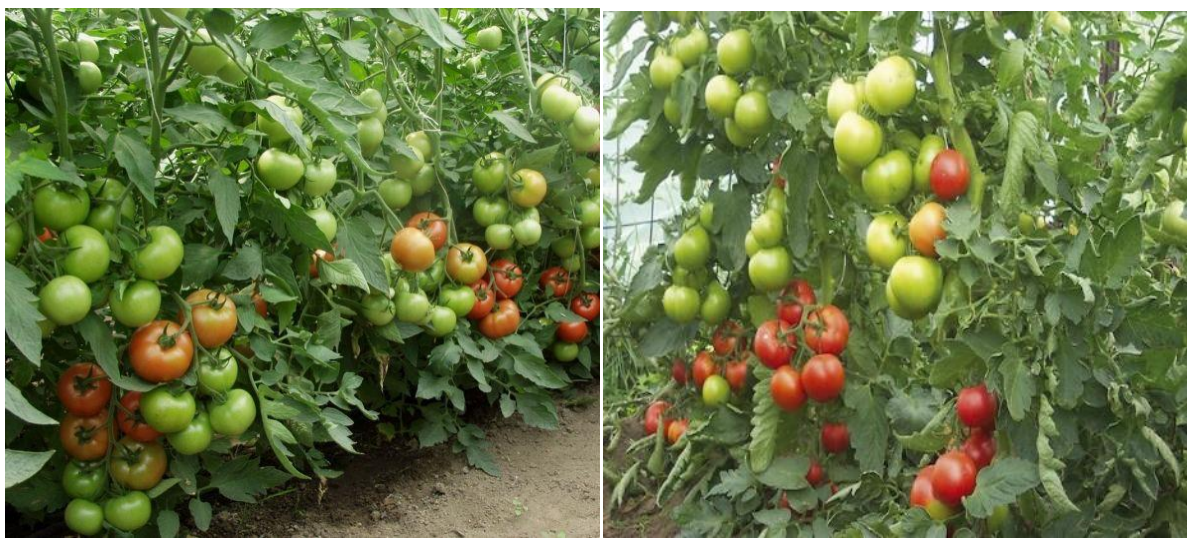

Figure 1. The scheme during the process of the experiment "randomized block" with four replications, factorial ANOVA, year cultivation 2015/2016.

\section{RESULTS AND DISCUSSION}

Biometric indicators of plant

The highness of the plant measured before cutting the tip of the plant, resulting in the limits from $155 \mathrm{~cm}$ (6 bloomed flower ) to 230.cm (10 bloomed flower), while the first floor heightens from the ground resulting in limits from 23.5 to $27.5 \mathrm{~cm}$ that are founded to the 8 bloomed flower. The distance between the third and three bloomed flower resulting with the limits 23.5 to $26.5 \mathrm{~cm}$. The thickness of the stem results in 1.25 to $1.53 \mathrm{~cm}$ (Table 1 ).

Table 1. Biometric indikator of the tomato hybrid Better boy

\begin{tabular}{llllll}
\hline Variants & $\begin{array}{l}\text { Height } \\
\text { plant }(\mathrm{cm})\end{array}$ & $\begin{array}{l}\text { Hight of fist } \\
\text { floor }(\mathrm{cm})\end{array}$ & $\begin{array}{l}\text { Nuber leaves } \\
\text { fist blooming }\end{array}$ & $\begin{array}{l}\text { Distance } \\
\text { between } \\
\text { blooming I- } \\
\text { IV }\end{array}$ & $\begin{array}{l}\text { Diameter of } \\
\text { stem }(\mathrm{cm})\end{array}$ \\
\hline 6 floor & 155 & 25.5 & 6.8 & 23.5 & 1.53 \\
\hline 8 floor & 178 & 23.5 & 5.8 & 25,5 & 1.35 \\
\hline 10 floor & 230 & 24.4 & 6.5 & 26.5 & 1.25 \\
\hline
\end{tabular}

The highness of the plant measured before cutting the tip of the plant, resulting in the limits from $175 \mathrm{~cm}$ (6 bloomed flower ) to $245 . \mathrm{cm}$ (10 bloomed flower), while the first floor heightens from the ground resulting in limits from 23.5 to $27.5 \mathrm{~cm}$. The distance between the third and three bloomed flower resulting with the limits 23.5 to $26.5 \mathrm{~cm}$. The thickness of the stem results in thelimits 1.33 to $1.29 \mathrm{~cm}$ (Table 2). 
Table 2. Biometric indikator of the tomato hybrid Juliet

\begin{tabular}{llllll}
\hline Variants & $\begin{array}{l}\text { Height plant } \\
(\mathrm{cm})\end{array}$ & $\begin{array}{l}\text { Hight of fist } \\
\text { floor }(\mathrm{cm})\end{array}$ & $\begin{array}{l}\text { Nuber } \\
\text { leaves fisrt } \\
\text { blooming }\end{array}$ & $\begin{array}{l}\text { Distance } \\
\text { between } \\
\text { blooming I-III }\end{array}$ & $\begin{array}{l}\text { Diameter of } \\
\text { stem }(\mathrm{cm})\end{array}$ \\
\hline 6 floor & 175 & 26.5 & 6.7 & 20.5 & 1.33 \\
\hline 8 floor & 173 & 25.5 & 5.4 & 22,3 & 1.36 \\
\hline 10 floor & 245 & 23.4 & 6.2 & 22.4 & 1.29 \\
\hline
\end{tabular}

The highness of the plant measured before cutting the tip of the plant, resulting in the limits from $152 \mathrm{~cm}$ ( 6 bloomed flower ) to $221 . \mathrm{cm}$ ( 10 bloomed flower), while the first floor heightens from the ground resulting in limits from 24.5 to $26.4 \mathrm{~cm}$.

Table 3. Biometric indikator of the tomato hybrid Amati

\begin{tabular}{llllll}
\hline Variants & $\begin{array}{l}\text { Height } \\
\text { plant }(\mathrm{cm})\end{array}$ & $\begin{array}{l}\text { Hight of fist } \\
\text { floor }(\mathrm{cm})\end{array}$ & $\begin{array}{l}\text { Nuber } \\
\text { leaves fisrt } \\
\text { blooming }\end{array}$ & $\begin{array}{l}\text { Distance } \\
\text { between } \\
\text { blooming I- } \\
\text { III }\end{array}$ & $\begin{array}{l}\text { Diameter of } \\
\text { stem }(\mathrm{cm})\end{array}$ \\
\hline 6 floor & 152 & 24.5 & 6.1 & 21.5 & 1.56 \\
\hline 8 floor & 154 & 22.5 & 5.2 & 24,5 & 1.37 \\
\hline 10 floor & 221 & 26.4 & 6.2 & 23.5 & 1.28 \\
\hline
\end{tabular}

Biometric indicators of fruit

For the indicators of fruit we can distinguish: H-D Report which is connected to the shape of the fruit in which case we can see that its value is in the limits 0.70-0.85. Even in the number of cubicles, the shown differences are small. So the numbers of cubicles for all in the study are in the values 3.5 to 5.0 where is shown a positive correlation in relation with the number of cubicles and average weight of fruits (Table 4).

Table 4. Biometric indicators of fruits Better boy

\begin{tabular}{|l|l|l|l|l|}
\hline Variants & $\begin{array}{l}\text { Epicarp widht } \\
(\mathrm{mm})\end{array}$ & $\begin{array}{l}\text { Number } \\
\text { fruits } \\
\text { chamber }\end{array}$ & $\begin{array}{l}\text { Average weight } \\
\text { of fruits (gr) }\end{array}$ & Ratio H-D \\
\hline 6 floor & $0.65 \mathrm{~mm}$ & 5 & $187.5 \mathrm{gr}$ & 0.7 \\
\hline 8 floor & $0.55 \mathrm{~mm}$ & 4 & 182.5 & 0.85 \\
\hline 10 floor & $0.45 \mathrm{~mm}$ & 4 & $177.5 \mathrm{gr}$ & 0.82 \\
\hline
\end{tabular}

Table 5.Biometric indicators Juliet

\begin{tabular}{|l|l|l|l|l|}
\hline Variants & $\begin{array}{l}\text { Epicarp } \\
\text { widht }(\mathrm{mm})\end{array}$ & $\begin{array}{l}\text { Number of fruits } \\
\text { chamber }\end{array}$ & $\begin{array}{l}\text { Average weight of } \\
\text { fruits (gr) }\end{array}$ & $\begin{array}{l}\text { Ratio H- } \\
\text { D }\end{array}$ \\
\hline 6 floor & $0.60 \mathrm{~mm}$ & 4 & $177.5 \mathrm{gr}$ & 0.85 \\
\hline 8 floor & $0.51 \mathrm{~mm}$ & 5 & 172.5 & 0.80 \\
\hline 10 floor & $0.47 \mathrm{~mm}$ & 4 & $178.5 \mathrm{gr}$ & 0.81 \\
\hline
\end{tabular}


Regarding the thickness of epikarp it is shown that the values of this indicator are in the limits of $0: 45-0.65 \mathrm{~mm}$, it appears that the differences between the hybrids are evident. In terms of average fruit weight, we can see a difference between the variants, so the highest weight is highlighted to the first variant respectively with 6 bloomed flowers $(187.54 \mathrm{~g})$.

1)

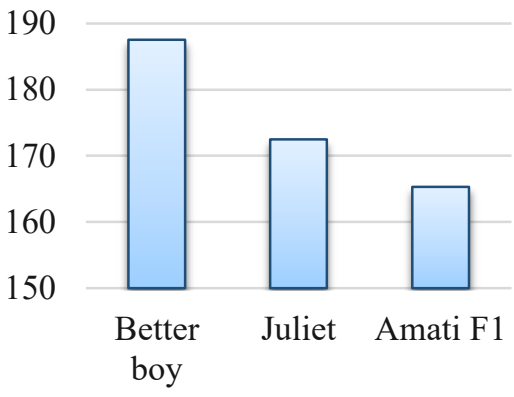

2)

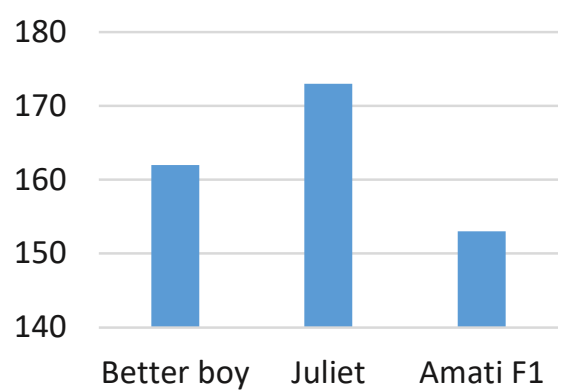

Graphic 1,2. Total yeld ton/ ha according the cultivar, year cultivation 2015/2016;

Average weight of fruits (gr) during vegetation, greenhaouse in Kosovo,2015/2016

General productivity for six harvest periods $\mathrm{t} / \mathrm{ha}$

From Graphics 2, we can notice that that highest productivity is realized to the three variant (10 bloomed flowers) and that $170 \mathrm{t} / \mathrm{ha}$, for Julet cultivar, while the lowest for Amati F1 $152 \mathrm{t} / \mathrm{ha}$ and Batter boy with $161 \mathrm{t} / \mathrm{ha}$.

\section{CONCLUSIONS}

Tomato is one of the most important and profitable vegetable crops in Kosovo. It is planted in the area over 2000 ha. Tomato fruits are consumed fresh in salads or cooked in sauces, soup and meat or fish dishes. They can be processed into purees, juices and ketchup.

Protected environments (greenhouses) are one of the most active forms of human activities in agriculture, taken into account the financial investment and human technologies addressed by it. The hybrid Amati F1, with 6 and 8 bloomed flowers results with early maturity and the best price in the market, but the production average is lower in comparison with other bloomed flowers. The highness of the plant measured before cutting the tip of the plant, resulting in the limits from $155 \mathrm{~cm}$ (6 bloomed flower) to $253 . \mathrm{cm}$ (10 bloomed flower). In terms of average fruit weight, we can see a difference between the variants, so the highest weight is highlighted to the first variant respectively with 6 bloomed flowers . 


\section{REFERENCES}

1. Alan O., OzdemiR N., Gunen N.Y., 2007. Effect of grafting on watermelon plant growth, yield and quality. Journal of Agronomy, 6: 362-365.

2. . BRAult D., StewART K.A., Jenni S., 2002. Growth, development, and yield of head lettuce cultivated onpaper and polyethylene mulch. HortSci 37, 92-94.

3. . Grassbaugh E.M., Regnier E.E., Bennett M.A.,Riedel R.M., 2004. Comparison of organic And inorganic mulches for heirloom tomato production. Acta Hort 638,

4. Peet, M. 1998. Greenhouse Tomato Production. North California State University.. Paduchuri P, Gohokar S, Thamke B, Subhas M (2010) Transgenic tomatoes. Int J Adv Biotechnol Res 2:69-72.

5. Knapp S (2002) Solanum section Geminata. Fl Neotrop 84:1-405.

6. . Diana M., Lazureanu A., Gogoasal I., Poiana M.A., Harmanescu1 M., Gergen I., 2007.

7. Influenceof NPK fertilization on nutrional quality of tomatoes. Buletin USAMV-CN, 64: 282-286.

8. . LEE J.M., 1994. Cultivation of grafted vegetables. I. Current status, grafting methods and benefits.HorticScience, 29: 235-239.

9. . Vu T, Choudhury NR, Mukherjee SK (2013) Transgenic tomato plants expressing artificial microRNAs for silencing the pre-coat and coat proteins of a begomovirus,

10. Tomato leaf curl New Delhi virus, show tolerance to virus infection. Virus Res 172.

11. . WIEN H.C, 1997. The physiology of vegetable crops . CAB Intnal., London, UK. 